\title{
GCU
}

Glasgow Caledonian

University

University for the Common Good

\section{The nature and extent of illegal drug and alcohol-related litter in Scottish social housing community: a photographic investigation}

Forsyth, Alasdair; Davidson, Neil

Published in:

Addiction Research and Theory

DOI:

10.3109/16066350802559464

Publication date:

2010

Document Version

Author accepted manuscript

Link to publication in ResearchOnline

Citation for published version (Harvard):

Forsyth, A \& Davidson, N 2010, 'The nature and extent of illegal drug and alcohol-related litter in Scottish social housing community: a photographic investigation', Addiction Research and Theory, vol. 18, no. 1, pp. 71-83. https://doi.org/10.3109/16066350802559464

\section{General rights}

Copyright and moral rights for the publications made accessible in the public portal are retained by the authors and/or other copyright owners and it is a condition of accessing publications that users recognise and abide by the legal requirements associated with these rights.

Take down policy

If you believe that this document breaches copyright please view our takedown policy at https://edshare.gcu.ac.uk/id/eprint/5179 for details of how to contact us. 


\title{
The nature and extent of illegal drug and alcohol-related litter
}

\author{
in Scottish social housing community: A photographic
}

\section{Investigation.}

\begin{abstract}
This paper investigates the nature and extent of alcohol and other-drug related litter in a residential community. This was done by means of a survey of such litter conducted in the social housing 'schemes' of a Scottish town, piloting the use of interpretive photography to assess the threat that these pose in the community ( $n=1,239$ pictures of such items). The survey found little evidence of hazardous illegal drug-related litter (no sets of needles / syringes) in comparison to alcohol litter such as broken bottles. The photographs taken also illustrated the ways in which the risks posed by such litter could vary, according to the type of items concerned (e.g. plastic versus glass, especially screw-cap, bottles) and their locations. It is also suggested that brand identifiable alcohol litter may act as form of free advertising. These findings are discussed in terms of community safety, and the need to raise awareness of the issues surrounding alcohol-related glass in a community setting as has already been done with illegal drug litter. It is also recommended that certain off-trade alcohol distributers switch from glass to plastic bottles.
\end{abstract}

Key words drug-litter, needle-stick, off-trade, glass, community safety, advertising

Word Count 3,265 


\section{Introduction}

Illegal drug-related litter has been widely identified as a community safety risk (e.g. BBC News, 2002; DEFRA, 2005; Hauck, 2004; O'Somachain, 2004; Taylor 2006; Wyatt et al, 1994), although the precise nature and level of this risk has been a subject of debate (e.g. Gunn, 1999; Nyiri et al, 2004; Philipp, 1993). The greatest concern has been directed towards discarded 'sharps' (i.e. sets of needles and syringes or $\mathrm{n} / \mathrm{s}$ ). These have even been portrayed as a potential health hazard to children, either through needle-stick injury risk or that their very presence may foster an interest in drugs. These fears are exemplified by a recent UK-wide high profile poster campaign, which posed a small child about to pick up a discarded syringe with the message "Drug dealers don't care where dirty needles end up, Do you?" (see Figure 1) http://www.crimestoppersscotland.com/drug_dealer.php, accessed 2007).

$<$ Figure 1>

The corresponding threat potential posed by legal drug litter, including smoking products, medicines and alcohol-related litter has not similarly been assessed. In particular, the risks posed by the unsafe disposal of alcohol products' glass bottles would seem to have parallels with the scenario concocted for Figure 1. However, to-date concerns about and assessments of the injury risk from alcohol containers has mainly focused on drinkers in on-trade licensed premises (i.e. glass vessels such as pint tumblers) (Cole et al, 1994; Forsyth, 2008; Lane et al, 2008; Warburton \& Shepherd, 2000) rather than on discarded off-trade glassware (i.e. broken bottles) or other alcohol-related litter (e.g. aluminium cans) in public space.

This research aims to evaluate the actual risk of scenarios such as that depicted in Figure 1, in a real world community setting, including those apparent from both illegal drug and alcoholrelated hazardous litter. The research also piloted the use of digital photography to document the extent and nature of illegal drug and alcohol-related litter within a residential area. The 
research for this paper was funded by the Alcohol Education Research Council (AERC) small grant scheme (under $£ 5 \mathrm{k}$ ) which supports projects such as this one which are of an innovative, primarily pilot, nature.

\section{Methods}

\section{Selection of Study Area}

The research undertaken for this paper took place in a town located within the central belt of Scotland, which was defined by the Scottish Urban-Rural Classification system (www.scotland.gov.uk/Publications/2006/07/31114822/9, accessed 2007) as an "other urban area" (i.e. with a population between 10,000 and 125,000). The town contained eight clearly defined post-war social housing developments ('schemes'), which henceforth are collectively referred to as the Study Area (population approximately 23,500 - just under half the total population of the town). The Study Area comprised of 30 census Data Zones, which had a mean deprivation rank of 2,498 out of Scotland's 6,505 Data Zones $(S D=1,124)$ according to the Scottish Index of Multiple Deprivation (SIMD) 2006. This figure is approximately $11 \%$ to the deprived side of SIMD mean (www.scotland.gov.uk/Topics/Statistics/SIMD/Overview).

Data obtained from the local health authority revealed that the town as a whole (including nearby villages) had an estimated problem drug user (PDU) population numbering more than 550 individuals and a corresponding estimate of more than 2,700 problem drinkers. Although it was not possible to relate the national PDU rate to the precise local geography of the Study Area, alcohol hospital admissions rates for the postcodes which covered the Study Area were obtained. These were found to vary around $10 \%$ on either side of the Scottish average (this was the case for the admission rates relating to both adults and young people in the Study Area). 
In summary, the Study Area was easily geographically defined and had relatively unremarkable demographic characteristics. With the exception of one small pocket of deprivation (population approximately 650) the Study Area did not include any neighbourhoods with extreme levels of either disadvantage or affluence and the extent of problematic substance use did not appear to deviate from what might be expected given the Study Area's level of disadvantage.

\section{Survey of drug and alcohol litter}

The research comprised a street survey of all illegal drug and alcohol-related litter within the Study Area. It should be noted that for the purposes of this study, alcohol products are defined as drinks containing an $\mathrm{ABV}$ above $0.5 \%$, in accordance with the legal definition used in Scotland (e.g. see Scottish Parliament, 2005), though in practice only one item was observed with an ABV below this (Panache shandy).

Fieldwork involved the researchers conducting block assessments (see Taylor et al, 1985), on foot, to observe and photograph all illegal drug and alcohol-related items lying within the residential environment of the Study Area. This observational survey covered all residential public space (e.g. streets, paths, etc.) within the Study Area but excluded any non-housing environments (e.g. parks, school playgrounds etc.), so that only that with the most direct impact on all residents was measured. (It is recognized that public parks, of which there was one adjacent to the Study Area, are likely to be locations of much outdoor drinking, e.g. see Forsyth \& Barnard, 2000; Galloway et al, 2006, and perhaps also some public drug use, e.g. Taylor, 2006, however including such locations were beyond the scope of this pilot research). Observations were conducted in late June and early July 2007 (which corresponds to the start of the school summer vacation in Scotland) during the daytime hours (9.30AM to 5.30PM). By using a local authority development plan map, tracts of streets were covered each day, weather 
permitting, in turn, until the whole Study Area had been surveyed.

By using a digital camera it was possible to confirm that every item of litter recorded was indeed from a drug or alcohol source, for example only alcohol litter which was clearly brand identifiable (photographic proof) was included in the survey. In practice this exclusion policy was fortuitous, as the Study Area was found to contain a vast amount of (mainly green) broken glass that was not readily visually brand identifiable in the field, the inclusion of which would have involved a much larger project than this study was capable of delivering. The physical condition (e.g. whether a bottle was intact or broken) of every item photographed and where it was located was recorded as a quantitative data set. This method also insured against double counts, and by the conclusion of fieldwork no photographed item remained unidentified.

The photographs taken also constituted (qualitative) data in their own right. In recent years, the employment of such visual methods (analysis of photographs or movies taken during fieldwork) has produced groundbreaking and informative findings in illegal drug research (e.g. Taylor et al, 2004; Rhodes et al, 2007). For example, interpretive photography has previously been used to identify, and map, risky outdoor illegal drug injection sites (Small et al, 2007) with a view towards designing out their inherent environmental risk to both users and the public (e.g. likelihood of drug litter). In the present study, the photographs taken illustrated graphically the risks represented by each item of litter (e.g. sharpness, location etc.).

The visual method employed was tested one afternoon by the researchers simply walking around the university and photographing any illegal drug or alcohol-related litter present in the adjacent Glasgow city centre streets. Brand identifiable alcohol-related litter was soon found, and successfully photographed, as were two separate instances of discarded n/s, both of which 
were located in a non-residential retail area, near a derelict former homeless hostel.

\section{Results}

Table 1 summarises the nature and extent of illegal drug and alcohol-related litter found within the Study Area. As can be seen from this table, despite the high profile nature of this issue, only six instances of potential illicit drug-related litter were photographed and none of these involved hazardous 'sharps' (sets of $\mathrm{n} / \mathrm{s}$ ). In contrast, more than fourteen hundred items of alcohol-related litter were found, much of it potentially hazardous (i.e. glass or metal). Table 1 also details the type of surface on which each item was photographed, either 'hard' (comprising paths, $n=333$ items of alcohol or other drug litter; underpasses, $n=98$; car parks, $n=70$; steps, $n=68$; footbridges, $n=47$; plazas, $n=42$; shop forecourts, $n=38$; lock-ups, $n=30$; bus stops, $n=27$; roadways, $n=7$; church concourses, $n=2$ and a phone booth, $n=1$ ), 'soft' (comprising either bushes, $n=484$ items or grass, $n=69$ ) or 'edge' surfaces (i.e. between 'hard' and 'soft' locations, specifically fences, $n=49$ items and walls, $n=47$ ).

\section{$<$ Table 1>}

Taking drug litter first, it was noteworthy that this included no sets of needles and syringes $(\mathrm{n} / \mathrm{s})$, especially considering two sets were quickly found during the equipment testing session around the university. All the drug litter recorded in this research was identified from just three photographs. Figure 2 is the first of these, which shows a used 'bong' (presumably for smoking cannabis), made from tin-foil wrapped around a smashed Buckfast tonic wine bottle neck, which was found and photographed among leaf litter in an underpass. The second of these, Figure 3 shows a cluster of four label-free plastic medicine bottles, which were found in a hedge along-side an unidentified glass beer-type bottle with the label pulled off (i.e. excluded from the data set) and two Buckfast bottles. Finally, Figure 4 shows an apparently unused pipe 'gauze' (potentially for crack-cocaine use) made from an unidentified bottle top, but which as 
with every other instance of illegal drug-related litter was found within photo-shot of Buckfast bottle remains.

$$
\begin{aligned}
& <\text { Figure } 2> \\
& <\text { Figure } 3> \\
& <\text { Figure } 4>
\end{aligned}
$$

A total of 1,406 individual items of alcohol-related litter were brand identified from 1,239 photographs (some photographs contained more than one item of the same brand in the same shot, maximum of 10 items). This litter included intact glass bottles, broken bottles, plastic bottles, cans, detached metal crown-caps (mainly from beer bottles), detached screw-caps (mainly from tonic wine or spirits bottles), detached labels and alcohol product packaging (e.g. cardboard boxes). Each of these types of litter obviously present different levels of risk, though in the extreme it was noteworthy that as many as 587 glass items (all bottles) should have been identified and photographed, $67.0 \%$ of which were already in a smashed condition.

By examining the photographs taken to produce Table 1, it was evident that the extent of risk represented by each type of alcohol-related litter varied by the nature of the item concerned, even between different types of smashed glass. To be certain of its alcoholic origins, only brand identifiable glassware was included. Broken bottles could firstly be identified from their label, if this was still attached $(n=259$ items, see Table 1$)$. Secondly, when no label was present, it was often possible to identify the brand concerned if the cap was still attached to the broken glass $(n=134)$. Figures 5 and 6 provide graphic examples of the relative risks of these two types of brand-identified broken glassware (both involve the same brand's bottles). Items held together by their label tended to be flattened, while capped items tended to involve jagged shards pointing dangerously outwards, a risk extended by the presence of a ring-seal.

$<$ Figure 5> 
$<$ Figure 6>

It should also be noted that $95.6 \%$ of all glassware identified from an attached cap was the screw-in type top (i.e. 129 of 135 such items photographed, usually the remains of tonic wine $n$ $=96$, or vodka $n=24$ ) as opposed to crown-caps. The latter design would therefore seem less capable of producing such hazardous litter (the numbers of detached bottle tops of each cap type where no glass was present was roughly the same, $n=227$ and 204 respectively).

Table 1 also indicates that glass risk may vary according to the type of surface upon which this alcohol-related litter was located. Almost three-quarters of intact bottles were photographed on 'soft' surfaces, the opposite from what was the case for broken bottles identified via their brand label (only one-third of broken glass with brand identifiable caps was photographed on soft surfaces). This implies that glass items deposited on 'hard' surfaces (e.g. concrete) are more likely to smash than those deposited on 'soft' surfaces (e.g. vegetation), arguably the very surfaces most often frequented by the public (i.e. on footpaths as opposed to in bushes).

A potential caveat to this assumption is that intact bottles may be more likely to be moved from some 'hard' surfaces to 'soft' surfaces by persons concerned about community safety, but who may be more wary about picking up broken glass. However, the level of community safety risk posed by alcohol (and drug) litter is also likely to vary according to accessibility and visibility, thus partially hidden items may be particularly hazardous, such as in the example depicted in Figure 7, where clear broken glass is partially embedded in grass. This contrasts with Figure 8, which shows a typical example of intact bottles in semi-hidden by bushes, the most common of all sites in which alcohol-related litter was photographed in this research. (Note - This local authority managed environment, of bushes surrounded by footpaths, was common throughout the post-war social housing 'schemes' which comprised the Study Area). 
$<$ Figure 7>

$<$ Figure 8>

The distribution of the various alcohol products identified was also interesting. In particular the dominance of one brand, Buckfast tonic wine, which represented an 35.1\% ( $n=494$ items) of all alcohol-related litter photographed and the majority of all glass, 318 bottles which were significantly more likely to be smashed than all 269 other bottles combined $(73.0 \%$ versus $60.1 \%$ respectively, chi-square $=10.867, p=0.001)$. Table 2 details all the alcohol products photographed using the brand identification technique.

$<$ Table 2>

\section{Discussion}

This research has piloted the use of interpretive photography in assessing the risks posed by substance use-related litter. The small scale and pilot nature of this project necessarily limited its scope, yet this in turn raised several issues for future research. Firstly the study was limited to social housing 'schemes'. It would have been interesting to compare these results with other environments, such as private housing developments, city centres, rural areas, parks etc. Secondly the research was conducted in one mid-sized town and it would be interesting to conduct a similar study in other towns, perhaps including those with a higher proportion of deprived areas. Thirdly the study focussed on alcohol and illegal drug litter. Tobacco / smoking products were not included, to do so would have involved a much larger study (use of photographs etc.). The same was true of non-substance use litter. On some occasions alcoholrelated litter was found within clusters of other refuse, while on others it was not (as is illustrated by Figures 2 to 8). In particular unidentified broken glass was not measured, nevertheless it was apparent during fieldwork that soft drinks containers tended to be plastic or aluminium (see Figure 8). Finally, the contents of litter bins were not measured and it would be interesting for future research to investigate whether alcohol and illegal drug-related litter were 
disposed of differently, in public safety terms, in comparison to other types of refuse.

Despite the above limitations, perhaps the most striking feature of this research was the absence of hazardous illegal drug-related litter in comparison to much greater extent of hazardous alcohol-related litter. This is not to deny the existence of discarded sets of needles and syringes, such items were easily found and photographed when testing the visual methodology around the university. Nor does this indicate an absence of problem drug users within the community survey (during fieldwork a resident was observed attempting to purchase ammonia and bicarbonate of soda form the local licensed grocers shop, but the shop-sever stated to the researchers that he had refused this sale as he suspected the man would manufacture crack-cocaine from these). What this finding does imply is that drug-related litter tends to be much less of a problem in residential communities, such as the social housing estates (schemes) where this research was conducted.

This is not entirely surprising, as research into the behaviour of 'street' drug injectors and crack-cocaine users has drawn attention to the secretive 'hidden' nature of their activities (Dovey et al, 2001; Rhodes et al, 2007; Small et al, 2007; Taylor, 2006). 'Street' injecting by illegal drug users, and by inference discarded needles, is an activity which would seem more suited to the anonymity of city centres, derelict buildings and waste ground, away from residential areas and the prying eyes of their / the wider community. By contrast 'street' drinking is a much more public affair, which can involve a degree of ostentatiousness and bravado, often in places where the public congregate (Brain, 1997; Forsyth \& Barnard, 2000; Galloway et al, 2007).

This research found no evidence to support the fears concerning drug-related litter in 
residential areas depicted in Figure 1. The same however could not be said of alcohol-related litter, which was often located at places where young children were at play. Fieldwork took place during the school holidays, and on many occasions the researchers had to wait for children to move on before being able to photograph an item of alcohol-related litter. One of these occasions illustrated the extent to which alcohol-related litter is part of the landscape of childhood. While photographing Figure 7, a group of children, perhaps aged between 10 and 12 years, shouted at the researchers "Look at them they are taking pictures of the Buckie (i.e. Buckfast tonic wine)" and "Imagine taking pictures of the Buckie" (field-note taken 04/07/07). From their position these children could not have seen what the researchers were actually photographing. It was striking therefore that they shouted this, rather than say 'taking pictures under the bushes' or of 'rubbish' / 'litter' or 'bottles' / 'glass', or 'drink' / 'booze', but instead they only mentioned a nickname for this one alcohol brand, and did so several times.

The above incident would appear to indicate just how accustomed children are to seeing this product lying around within their neighbourhood. Buckfast did not appear to be overtly promoted (i.e. by distributors) in the Study Area, although on the evidence of this incident alone it hardly needs to be. This begs the question of whether all the alcohol-related litter photographed during this research might be regarded as an informal advertising route, one which is free, viral and most likely to reach (and arguably influence) children, who are likely to be both physically closer to the line-of-sight to these items and the most likely to frequent (i.e. play) in the public spaces which these discarded alcohol containers occupy. This possibility requires further investigation. Indeed recent research with young 'street drinkers' conducted in another part of central Scotland noted that "As with other alcoholic drinks preferred by street drinkers, participant's knowledge of Buckfast seemed to have been gleaned through word of mouth. Indeed drinking Buckfast was considered so normative as to be considered part of 
growing up." (Galloway et al, page 75) and quotes one focus group participant as stating "I mean the number of times you walk down the street and you see basically bottles of Buckfast lying smashed on the ground..." (page 99).

It was also noteworthy that all the suspected drug-related litter in this research was photographed lying next to Buckfast bottles. In this respect illegal drug-related litter within residential communities would appear to be nothing more than an extension of alcohol-related litter, with the latter being the more hazardous. Most of the glass photographed in this research was already smashed, especially Buckfast bottles which constituted the majority of this most hazardous type of litter. This non-random product smashing, taken together with photographs showing such remains lying next to broken paving stones or metal posts, implies that much of this broken glass may not have been accidental. Intentional smashing of alcohol products' bottles by outdoor drinkers has also been identified as a public safety concern by some recent research (Human Factors Analysts Limited, 2007; Galloway et al, 2007). As such there would appear to be a strong case for manufacturing some off-trade alcohol products in plastic containers (especially those commonly found amongst alcohol-related litter in public space - as is already the case with white cider and soft drinks). There have been calls for this to be done with Buckfast (BBC News, 2006; Gough 1994) including because of their alleged frequent use as weapons in street assaults (Robertson, 2003) however the distributers have so far been resistant to these, claiming their product represents less than half of one percent of the Scottish alcoholic beverages market (McMillan, 2005; Mann, 2007). In our research this beverage was responsible for the majority of hazardous glass and its' screw-cap bottle design appeared to create worsen this risk, one which would not exist if it were corked.

Returning to the view expressed in Figure 1, that "drug dealers don't care" where their empties 
are discarded. This may or may not be true of illegal drug dealers (we suspect that illegal drug dealers do in fact care, as among other cares they are likely to be wary of discarded n/s sets attracting police attention), but can this allegation (also) be levelled at alcohol dealers? In contrast to the publicity (and research attention) received by illegal drug-related litter, the threat posed by alcohol-related litter seems somewhat greater, yet ignored. On the evidence of this research, and given that the greatest risk from alcohol-related litter may be faced by nondrinkers (i.e. children) this is a hazard which clearly deserves to receive more publicity than that of drug-related litter.

\section{Conclusions}

In comparison to the high profile issue of illegal drug-related litter, alcohol-related broken glass in the community is clearly a neglected environmental health concern. Additionally the sheer scale of brand identifiable alcohol-related litter in residential neighbourhoods would seem to represent a form of free, viral, advertising, and one which is particularly easily noticed by children. Measures to combat this should include that alcohol products demonstrated to be prevalent amongst hazardous street glass be manufactured more responsibly, such as in plastic containers, and an alcohol-related litter awareness campaign, such as that already undertaken for drug-related litter, though this may not be as politically or financially attractive to potential policy-makers, campaigners, researchers, etc. as is anti-illegal drug publicity measures. 


\section{References}

BBC News (2002) Dumped needles pose health threat (on-line article). April $15^{\text {th }}$. http://news.bbc.co.uk/1/hi/health/1929068.stm

BBC News (2006) Plastic Buckfast bottles petition (on-line article). May $10^{\text {th }}$. http://news.bbc.co.uk/1/hi/scotland/glasgow_and_west/4753439.stm

Brain, K. \& Parker, H. (1997) Drinking with Design: Alcopops, designer drinks and youth culture. London: The Portman Group.

Cole, J., Plant, M., Miller, P., Plant, M. \& Nichol, P. (1994) Preventing injuries from bar glasses. British Medical Journal, 308, 1237 - 1238.

Conran, S. (2008) Back to the drawing board: Crime and the Design Alliance. Paper presented at the International Crime Science Conference. British Library $17^{\text {th }}$ July.

DEFRA (2005) Tackling Drug related Litter: Guidance and good practice. London: Department for Environment Food and Rural Affairs. http://www.defra.gov.uk/environment/localenv/litter/pdf/drugrelatedlitter.pdf

Dovey, K., Fitzgerald, J. \& Choi, Y. (2001) Safety Becomes Danger: Dilemmas of drug use in public space. Health \& Place, 7, $319-331$.

Forsyth, A. J. M. (2008) Banning glassware from nightclubs in Glasgow (Scotland): Observed impacts, compliance and patron's views. Alcohol \& Alcoholism, 43: 1, $111-117$.

Forsyth, A. J. M. \& Barnard, M. (2000) Preferred Drinking Locations of Scottish Adolescents, Health and Place, 6: 2, 105 - 115.

Galloway, J., Forsyth, A. J. M. \& Shewan, D. (2007) Young People's Street Drinking Behaviour: Investigating the influence of marketing \& subculture. London: Alcohol Education Research Council.

http://www.aerc.org.uk/documents/pdf/finalReports/044Steet_Drinking.pdf

Gough, J. (1994) Bottle up Buckie in Plastic: Safety plea to combat litter peril. Evening Times, December $2^{\text {nd }}$.

Gunn, A. (1999) Discarded Needles Risk Tiny. (Letter) The Courier-Mail, February $2^{\text {nd }}$.

Hauck (2004) Project Orinoco: Engaging the community with drug Litter campaigns. Debrief presentation prepared for ENCAMS the charity which runs Keep Britain Tidy campaign. Teddington Middlesex: Hauck.

http://www.defra.gov.uk/environment/localenv/litter/pdf/druglitter-community.pdf

Human Factors Analysts Limited (2007) The relationship between off-sales and problem drinking in Scotland. Edinburgh: Scottish Executive.

http://www.scotland.gov.uk/Publications/2007/06/15155717/0

Lane, D., Wright, G., Webb, T. \& Awar, S. (2008) Scatter patterns from beer glasses used as 
weapons. Paper presented at the International Crime Science Conference. British Library $17^{\text {th }}$ July.

McMillan, A. (2005) Buckfast sales surge after Jamieson appeal for ban. The Scotsman, May $8^{\text {th }}$.

Mann, G. (2007) We Need to get Against Alcohol: Hitting out ... Jim Wilson, Scottish Manager of J. Chandler \& Co (Buckfast) Ltd., has called for the introduction of ID cards to help tackle under age drinking. Airdrie \& Coatbridge Advertiser, November $8^{\text {th }}$.

Nyiri, P., Leung, T. \& Zuckerman, M. A. (2004) Sharps discarded in inner city parks and playgrounds - risk of blood-borne virus exposure. Communicable Disease and Public Health, $7: 4,287-288$.

O’Somachain, E. (2004) Tackling Sharps. Environmental Health Journal, May: 154 - 155.

Philip, R. (1999) Community needlestick accident data and trends in environmental quality. Public Health, 107: 5, 363 - 369.

Rhodes, T., Briggs, D., Holloway, G., Jones, S. \& Kimber, J. (2007) Visual Assessment of Injecting Drug Use: A pilot study. London, National Treatment Agency for Substance Misuse. http://www.nta.nhs.uk/publications/documents/nta_visual_assessments_injecting_drug_use_20 06_rb13.pdf

Robertson, A. (2003) Buckfast Plastic Bottles Plea to Cut Horror Attacks: Top cop's appeal after latest assault in the city highlights dangers of glass. Evening Times, August $6^{\text {th }}$.

Scottish Parliament (2005) Licensing (Scotland) Act 2005

http://www.scottish.parliament.uk/business/bills/pdfs/b37s2.pdf.

Small, W., Rhodes, T., Wood, E. \& Kerr, T. (2007) Public Injecting Settings in Vancouver: Physical environment, social context and risk. International Journal of Drug Policy, 18: 1, 27 36.

Taylor, A., Fleming, A., Rutherford, J. \& Goldberg, D. (2004) Examining the Injecting Practices of Drug Users in Scotland. Edinburgh: Scottish Executive Effective Interventions Unit.

http://www.scotland.gov.uk/Resource/Doc/47210/0013525.pdf

Taylor, A. with Cusick, L., Kimber, J., Hickman, M. \& Rhodes, T. (2006) The Social Impact of Public Injecting. Independent Working Group on Drug Consumption Rooms, Paper D. York Joseph Rowntree Foundation.

http://www.jrf.org.uk/bookshop/ebooks/Taylor-DCR-D.pdf

Taylor, R. B., Shumaker, S. A. \& Gottfredson, S. D. (1985) Neighborhood-level Links between Physical Features and Local Sentiments: Deterioration, fear of crime, and confidence. Journal of Architectural Planning and Research, 2: 4, 261 - 275.

Warburton, A. L. \& Shepherd, J. P. (2000) Effectiveness of Toughened Glassware in Terms of Reducing Injury in Bars: A randomised controlled trial. Injury Prevention, 6, 36 - 40. 
Wyatt, J. P., Robertson, C. E. \& Scobie, W. G. (1994) Out of hospital needlestick injuries. Archives of Disease in Childhood, 70: 3, 245 - 246. 
Figure 1: Anti-Drug Litter Poster

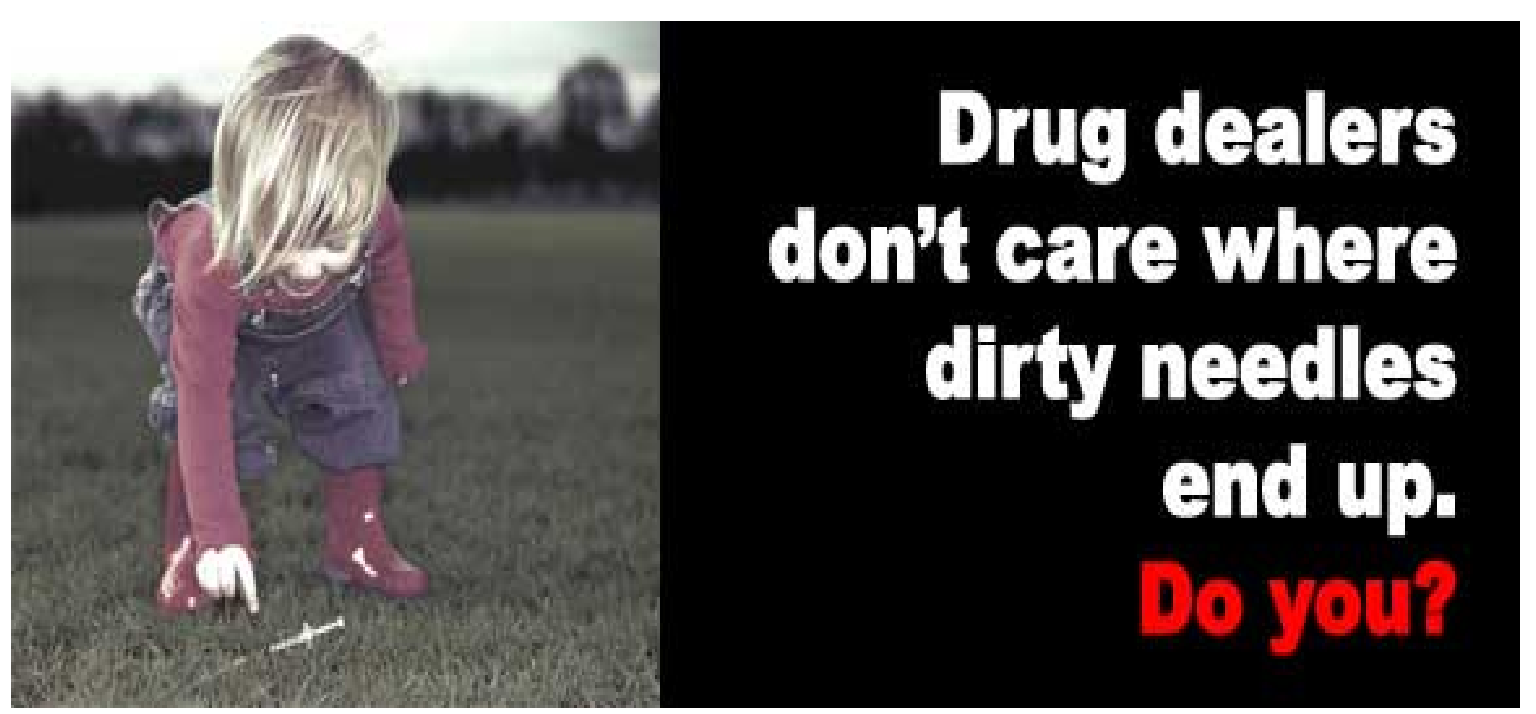


Figure 2: Photograph of improvised bong (centre right)

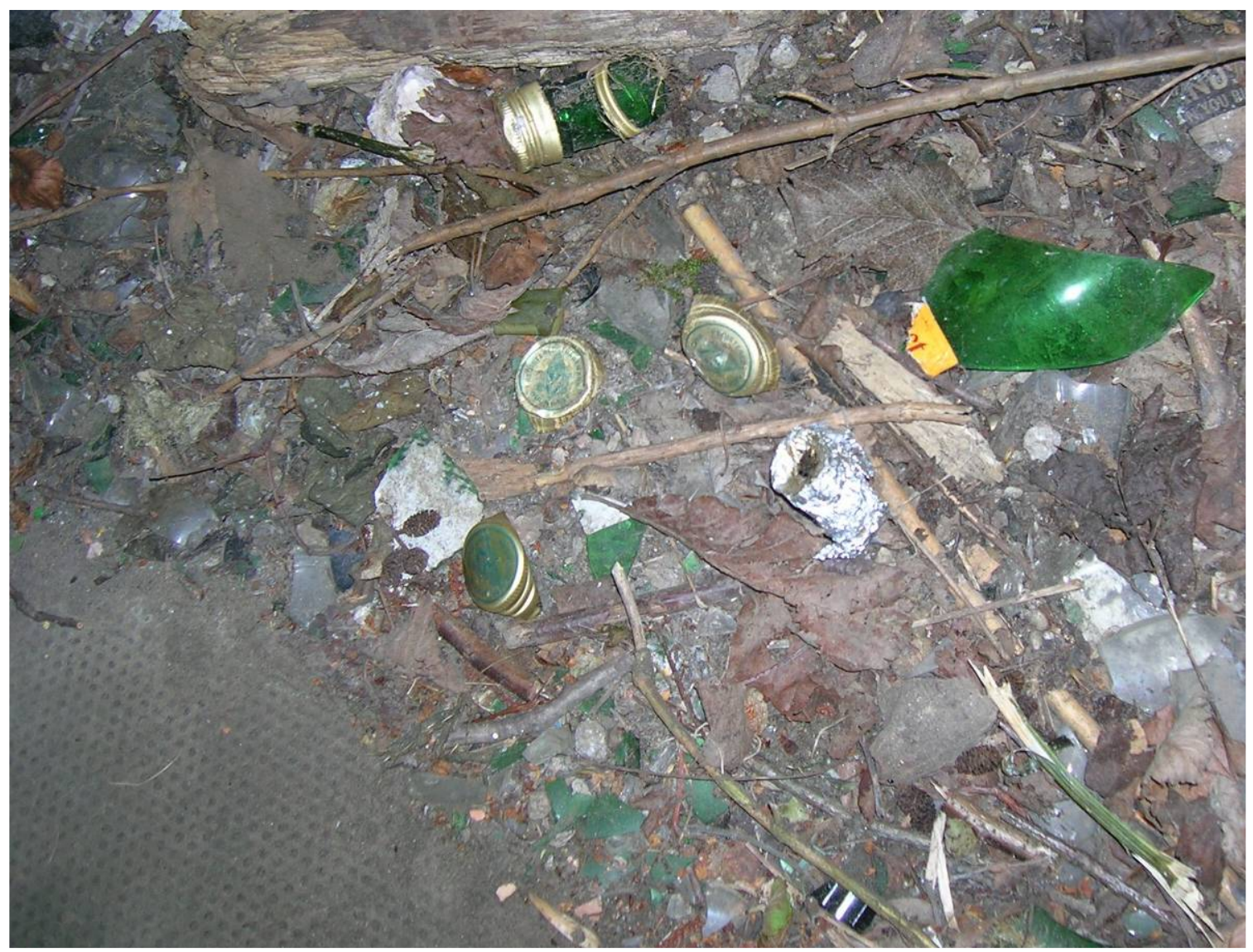


Figure 3: Photograph of plastic medicine bottles (lower half of shot)

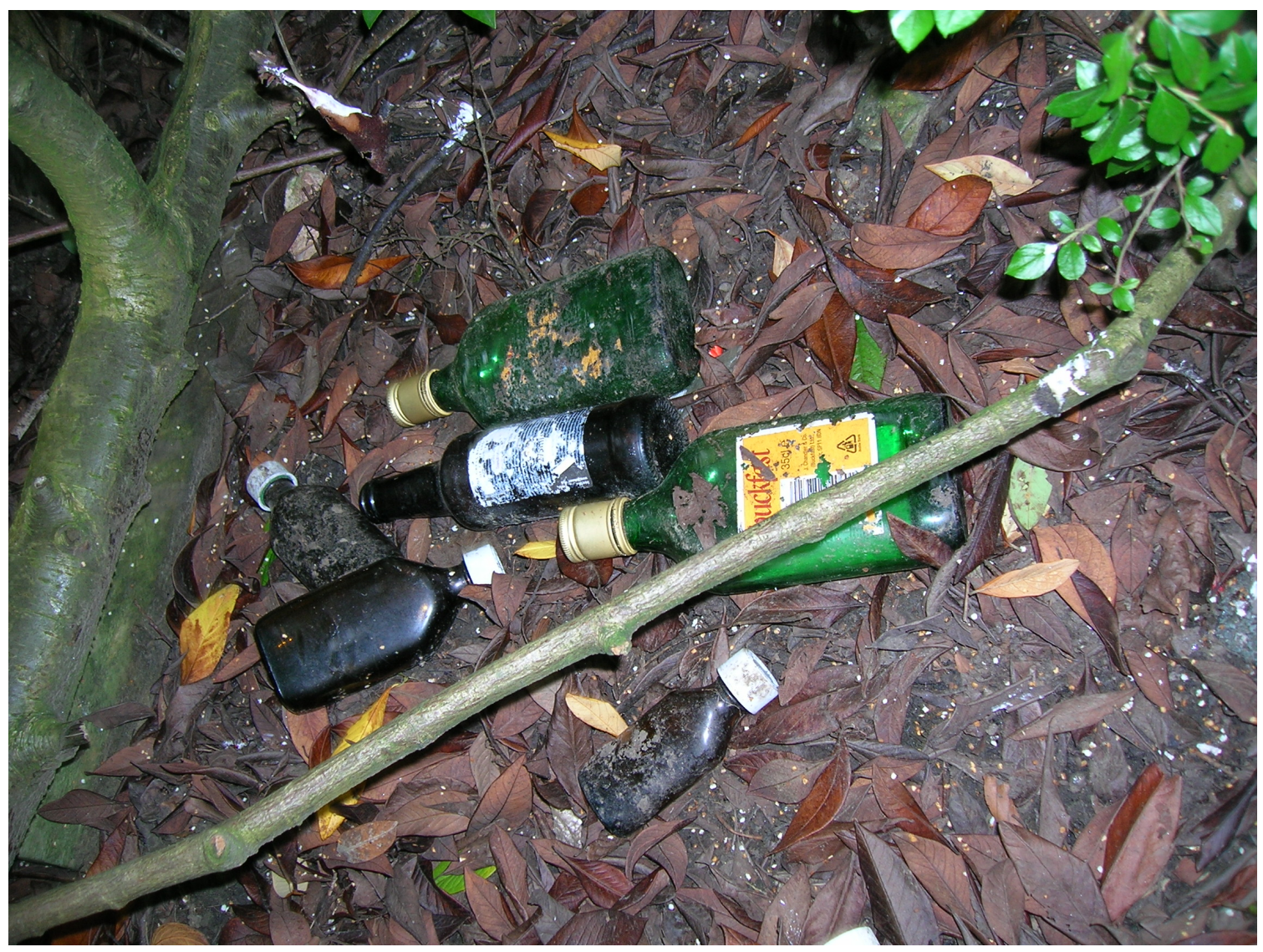


Figure 4: Photograph of improvised pipe (lower left)

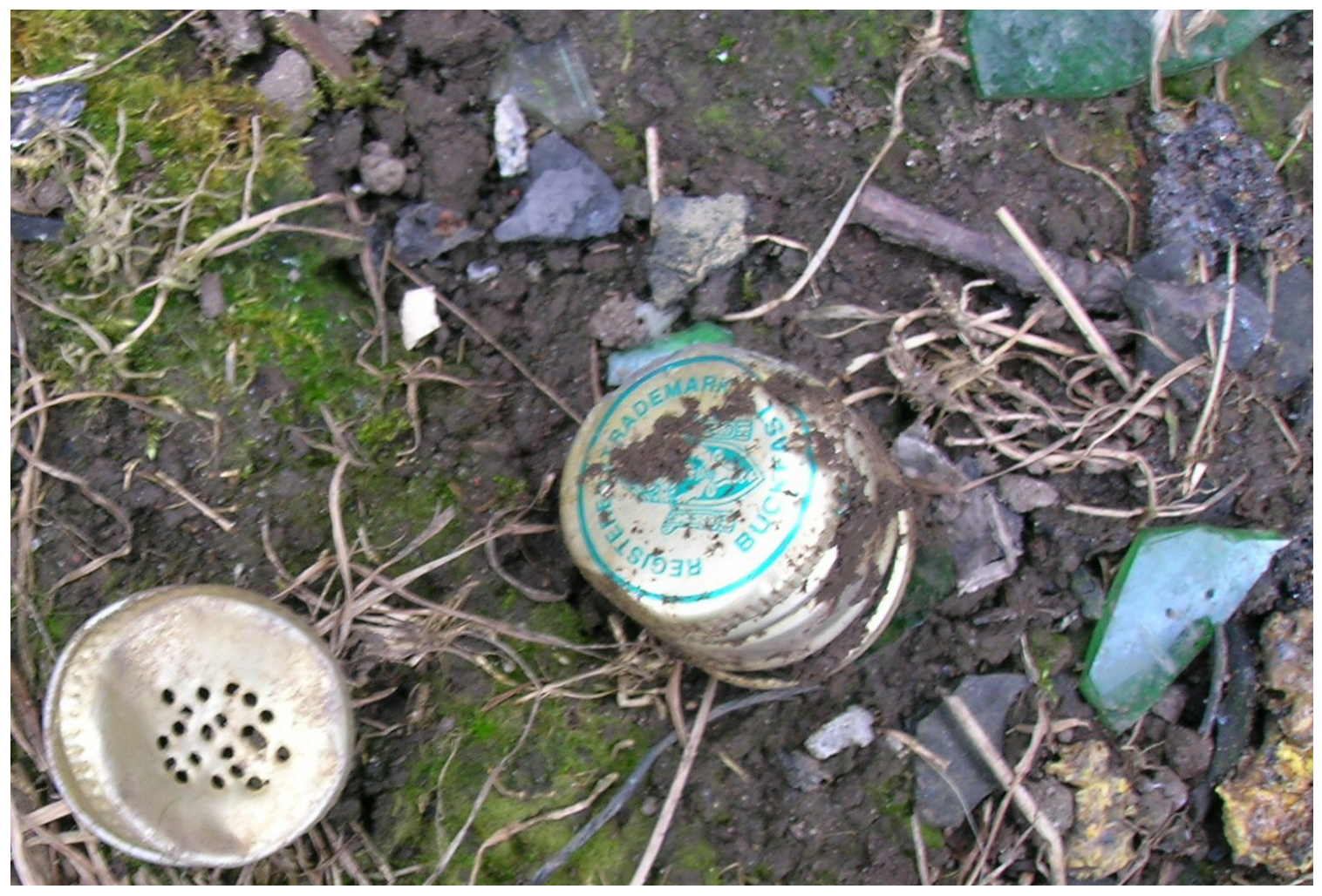


Figure 5: Photograph of glass held together by a label (on footpath)

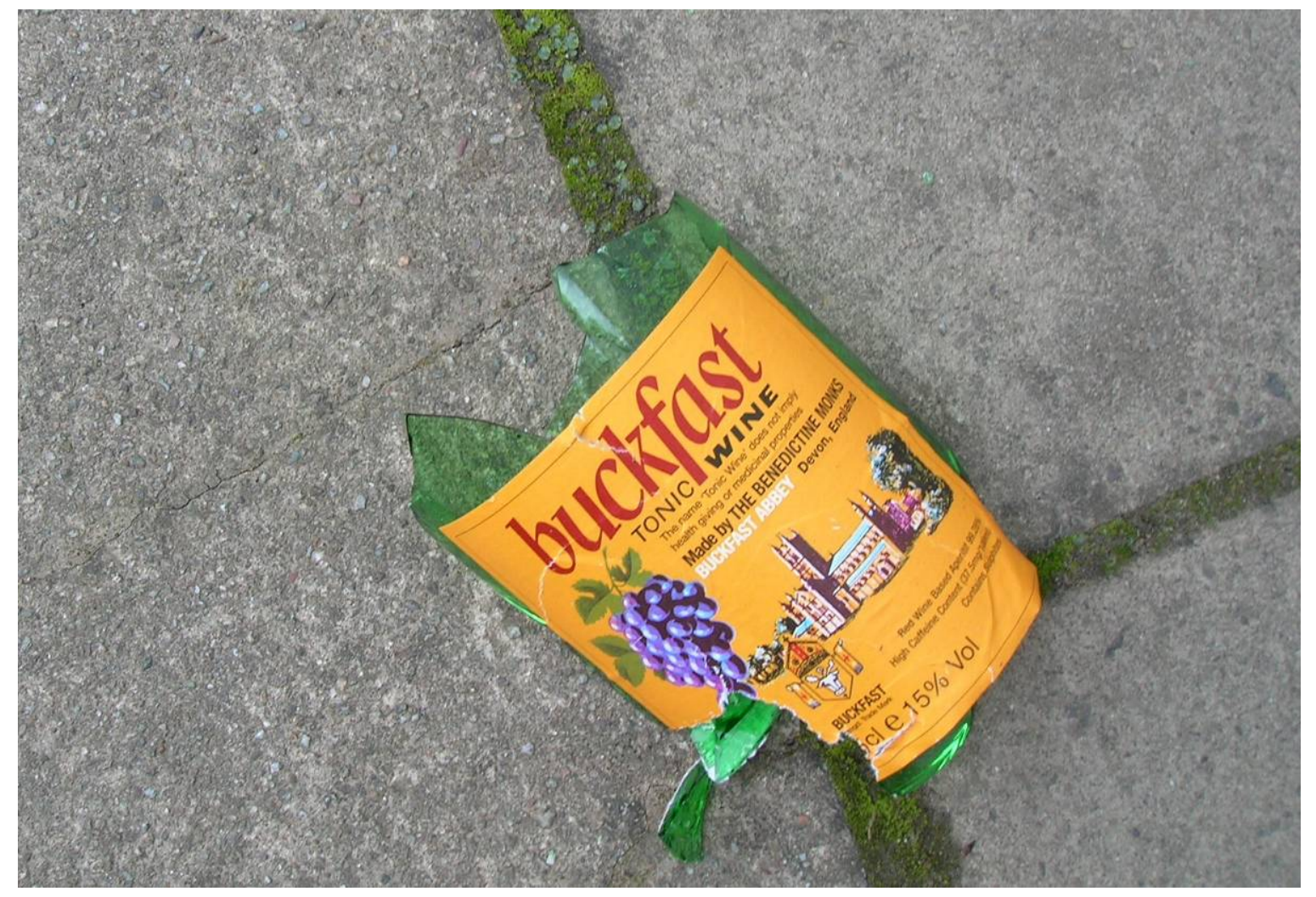


Figure 6: Photograph of glass held together by 'screw-cap' (on grass verge)

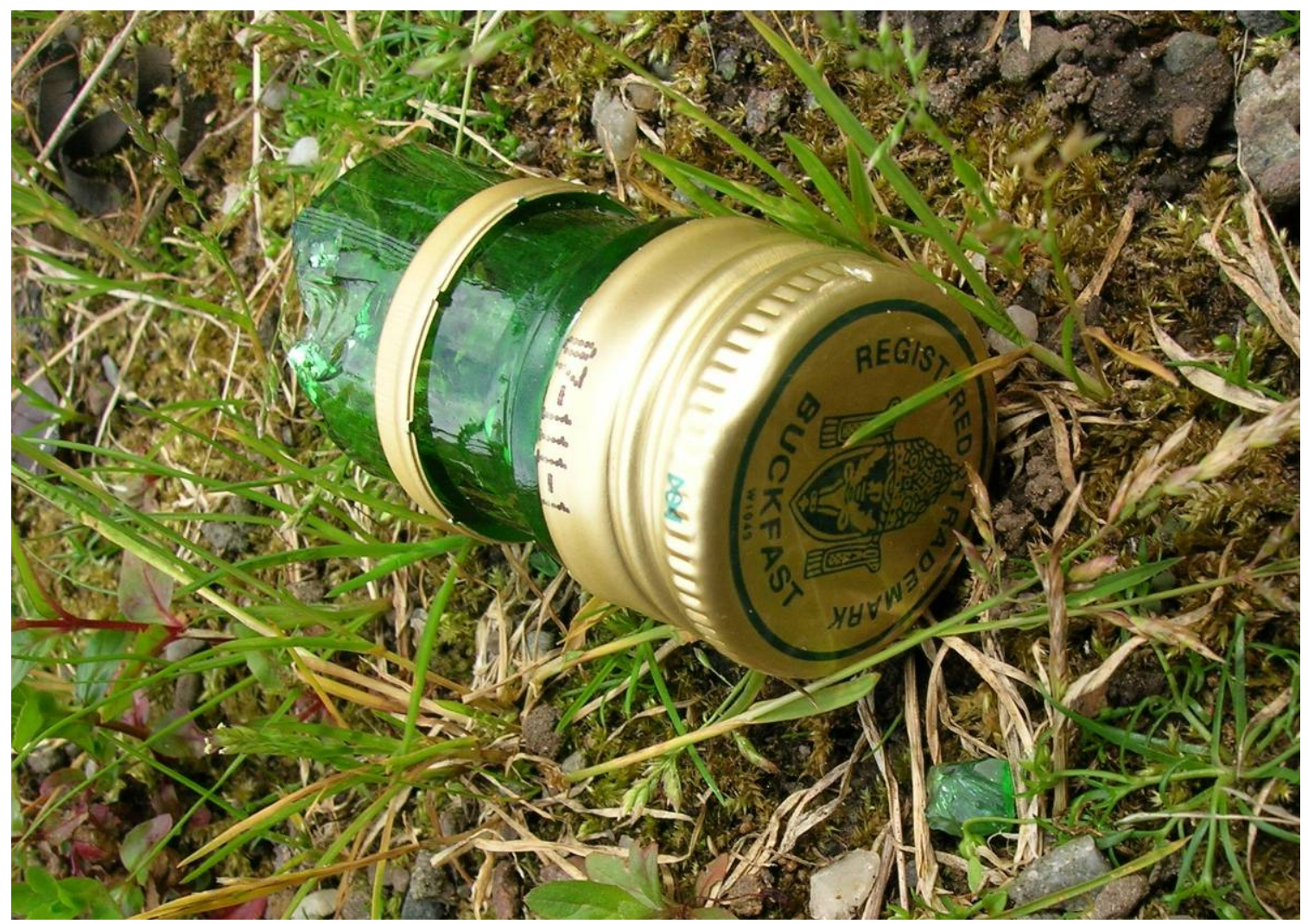


Figure 7: Photograph of alcohol-related glassware in high risk locus

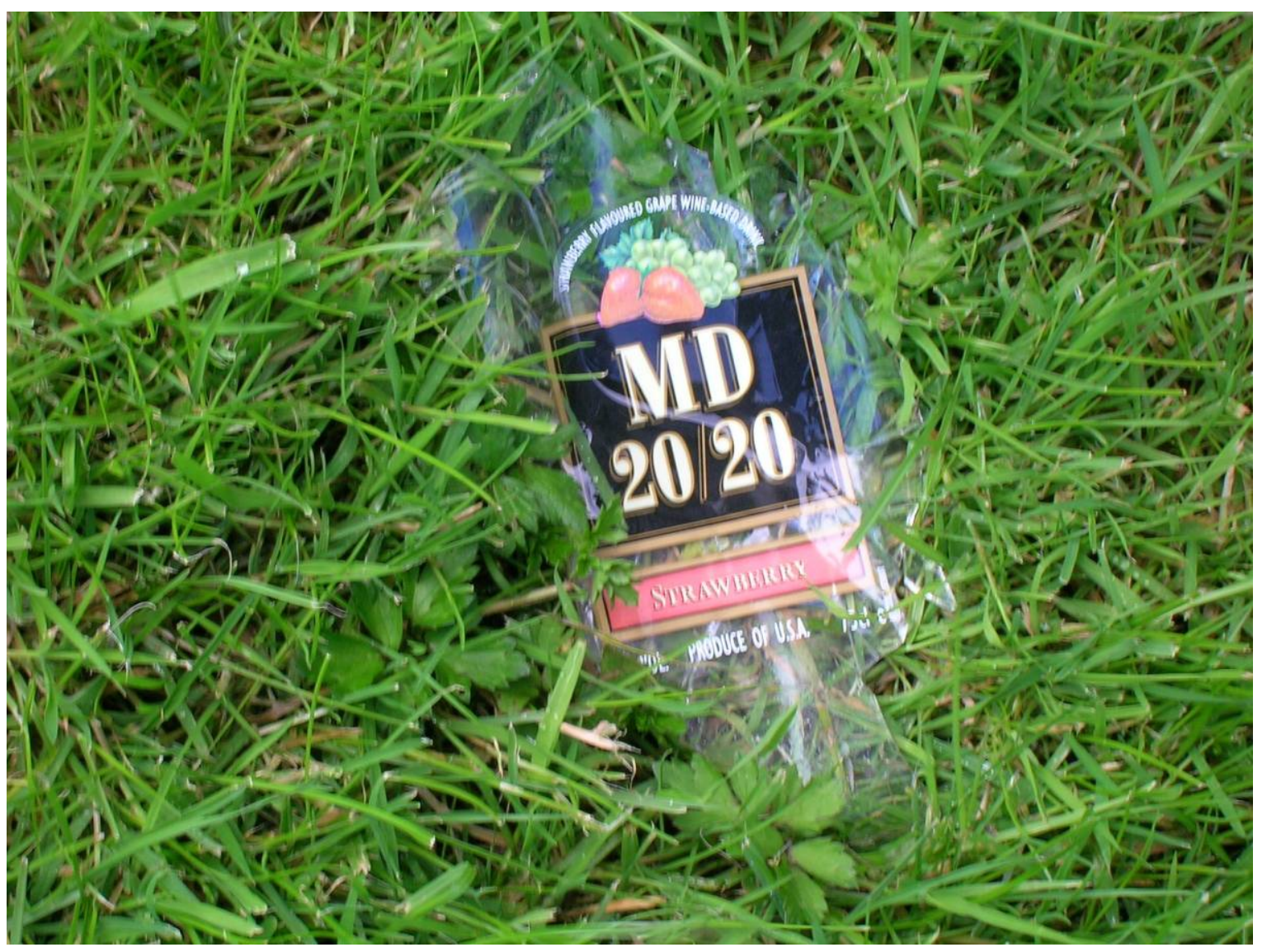


Figure 8: Photograph of alcohol-related glassware in lower risk locus

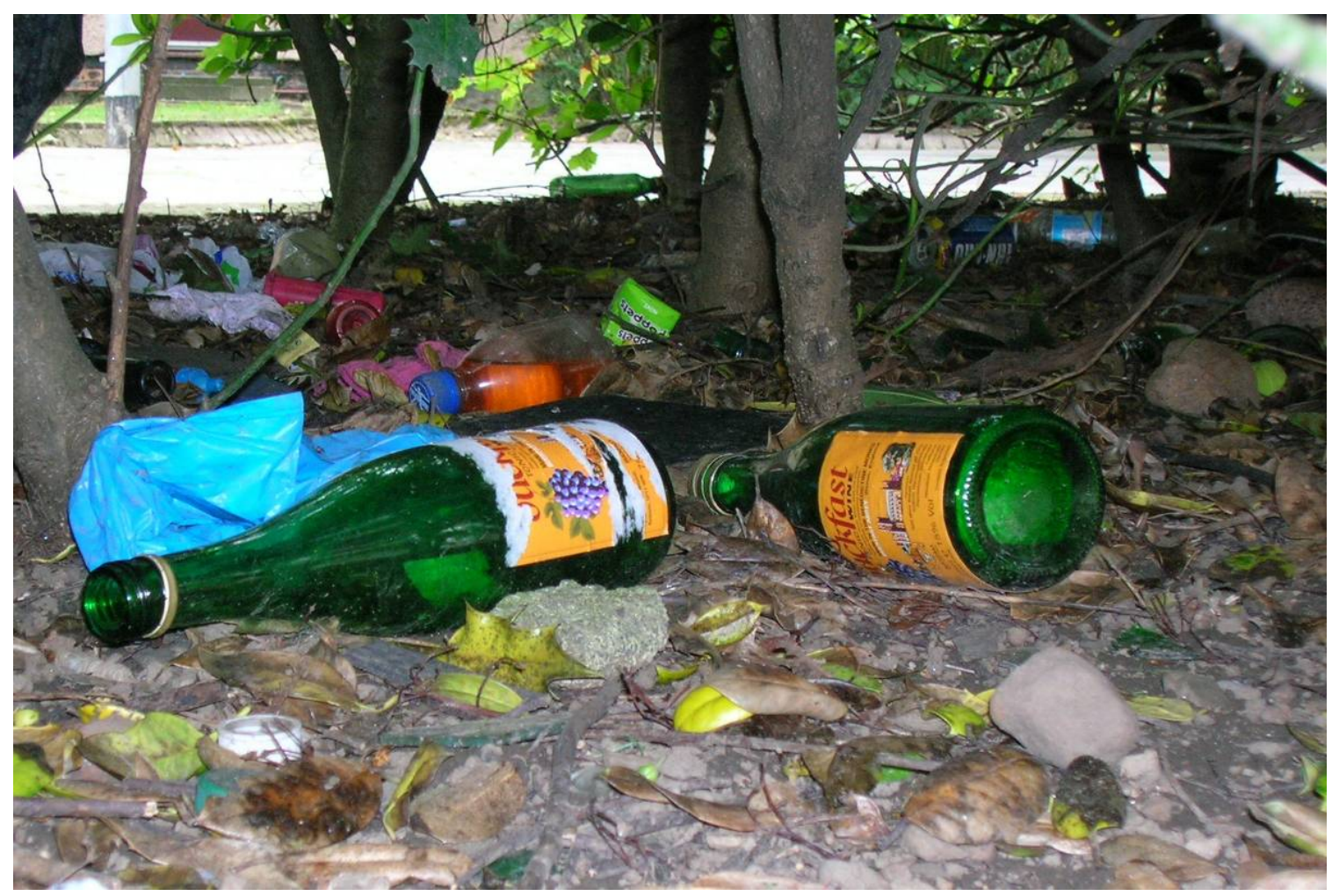


Table 1: Illegal drug or alcohol-related litter and the type of locus where it was photographed / discarded

\begin{tabular}{|l|c|c|c|c|}
\hline $\begin{array}{r}\text { Location } \\
\text { Litter Item }\end{array}$ & $\begin{array}{c}\text { 'Hard' } \\
\text { surface }\end{array}$ & $\begin{array}{c}\text { 'Edge' } \\
\text { surface }\end{array}$ & $\begin{array}{c}\text { 'Soft' } \\
\text { surface }\end{array}$ & $\begin{array}{c}\text { Any } \\
\text { location }\end{array}$ \\
\hline \multicolumn{5}{|l|}{ Drug Litter } \\
\hline Needles/Syringes & 0 & 0 & 0 & 0 \\
\hline Smoking devices & 1 & 0 & 1 & 2 \\
\hline Plastic containers & 0 & 0 & 4 & 4 \\
\hline Total Drugs & $\mathbf{5}$ & $\mathbf{5}$ & $\mathbf{5}$ & $\mathbf{6}$ \\
\hline \multicolumn{5}{|l|}{} \\
Alcohol Litter & $25(12.9 \%)$ & $27(13.9 \%)$ & $142(73.7 \%)$ & 194 \\
\hline Intact Bottles & $199(76.5 \%)$ & $12(4.6 \%)$ & $49(18.9 \%)$ & 260 \\
\hline Glass with label & $79(58.5 \%)$ & $11(8.2 \%)$ & $45(33.6 \%)$ & 135 \\
\hline Glass with cap & $307(71.2 \%)$ & $12(2.8 \%)$ & $112(26.0 \%)$ & 431 \\
\hline Cap only & $12(66.7 \%)$ & $3(16.7 \%)$ & $3(16.7 \%)$ & 18 \\
\hline Label only & $122(37.7 \%)$ & $28(8.6 \%)$ & $174(53.7 \%)$ & 324 \\
\hline Cans & $9(47.4 \%)$ & $3(15.8 \%)$ & $7(36.8 \%)$ & 19 \\
\hline Packaging & $9(36.0 \%)$ & $0(-)$ & $16(66.7 \%)$ & 25 \\
\hline Plastic containers & $\mathbf{7 6 2 ( 5 4 . 2 \% )}$ & $\mathbf{9 6}(6.8 \%)$ & $\mathbf{5 4 8 ( 3 9 . 0 \% )}$ & 1406 \\
\hline Total Alcohol & &
\end{tabular}


Table 2: Alcohol-related litter by product (with example brands)

\begin{tabular}{|c|c|c|c|c|c|}
\hline Beverage & Glass Bottles & Plastic Bottles & Metal Cans & Other (caps, packs etc.) & Total Litter \\
\hline Ordinary lager (e.g. Tennent's) & $153(26.0 \%)$ & $0(-)$ & $228(70.4 \%)$ & $197(42.1 \%)$ & $578(41.1 \%)$ \\
\hline Super-lager (e.g. Tennent's Super) & $0(-)$ & $0(-)$ & $29(9.0 \%)$ & $0(-)$ & $29(2.1 \%)$ \\
\hline Ales / Stout (e.g. Tennent's Special) & $0(-)$ & $0(-)$ & $9(2.8 \%)$ & $3(0.6 \%)$ & $12(0.9 \%)$ \\
\hline Ordinary Cider (e.g. Strongbow) & $2(0.3 \%)$ & $3(12.0 \%)$ & $39(12.0 \%)$ & $2(0.4 \%)$ & $46(3.3 \%)$ \\
\hline White Ciders (e.g. Strongbow Super) & $6(1.0 \%)$ & $10(40.0 \%)$ & $19(5.9 \%)$ & $9(0.2 \%)$ & $44(3.1 \%)$ \\
\hline Pear Cider / Perry (e.g. Lambrini) & $5(0.8 \%)$ & $0(-)$ & $0(-)$ & $0(-)$ & $5(0.4 \%)$ \\
\hline Table Wine (e.g. Jacobs Creek) & $4(0.7 \%)$ & $0(-)$ & $0(-)$ & $1(0.2 \%)$ & $5(0.4 \%)$ \\
\hline Sparking Wine (i.e. Beringer) & $1(0.2 \%)$ & $0(-)$ & $0(-)$ & $0(-)$ & $1(0.1 \%)$ \\
\hline Tonic Wine (i.e. Buckfast) & $318(54.0 \%)$ & $0(-)$ & $0(-)$ & $176(37.6 \%)$ & $494(35.1 \%)$ \\
\hline Fortified Wine / Sherry (e.g. $Q C$ ) & $3(0.5 \%)$ & $0(-)$ & $0(-)$ & $0(-)$ & $3(0.2 \%)$ \\
\hline Vermouth (i.e. Martini) & $0(-)$ & $0(-)$ & $0(-)$ & $1(0.2 \%)$ & $1(0.1 \%)$ \\
\hline Whisky / Bourbon (e.g. Jack Daniel's) & $6(1.0 \%)$ & $0(-)$ & $0(-)$ & $6(1.3 \%)$ & $12(0.9 \%)$ \\
\hline Rum (i.e. Stroh) & $0(-)$ & $0(-)$ & $0(-)$ & $1(0.2 \%)$ & $1(0.1 \%)$ \\
\hline Vodka (e.g. Smirnoff) & $49(8.3 \%)$ & $0(-)$ & $0(-)$ & $39(8.3 \%)$ & $88(6.3 \%)$ \\
\hline Spirit Miniatures (i.e. Smirnoff) & $0(-)$ & $12(48.0 \%)$ & $0(-)$ & $0(-)$ & $12(0.9 \%)$ \\
\hline Alcopops (e.g. Smirnoff Ice) & $18(3.1 \%)$ & $0(-)$ & $0(-)$ & $28(6.0 \%)$ & $46(3.3 \%)$ \\
\hline Liqueurs (e.g. Irish Meadow) & $2(0.3 \%)$ & $0(-)$ & $0(-)$ & $0(-)$ & $2(0.1 \%)$ \\
\hline Fortified Beverages (e.g. $M D 20 / 20$ ) & $18(3.1 \%)$ & $0(-)$ & $0(-)$ & $0(-)$ & $18(1.3 \%)$ \\
\hline NRG Drinks (e.g. Red Square) & $4(0.7 \%)$ & $0(-)$ & $0(-)$ & $4(0.9 \%)$ & $8(0.6 \%)$ \\
\hline
\end{tabular}


